\title{
KOMPLEMENTARNA MEDICINA U PSIHIJATRIJI
}

\author{
Robert Barbarić1 ${ }^{1,2} \&$ Ivan Vasilj ${ }^{1}$ \\ Fakultet zdravstvenih studija Sveučilišta u Mostaru ${ }^{1}$ \\ Klinika za psihijatriju Sveučilišne kliničke bolnice Mostar² \\ 88000 Mostar, Bosna i Hercegovina
}

Rad je primljen 28.09.2020.. Rad je recenziran 14.10.2020. Rad je prihvaćen 19.10.2020.

\section{SAŽETAK}

Zvanična medicina posljednjih desetljeća u liječenje osoba s duševnim smetnjama počinje uvrštavati prirodne lijekove i duhovnu terapiju, a posljednjih godina sve se češće među liječnicima i zdravstvenim radnicima spominju alternativne i komplementarne metode u liječenju psihičkih poremećaja. Alternativna medicina podrazumijeva „ostale načine liječenja“ i mnogo je ispravniji izraz komplementarna koja daje nadopunu zvaničnoj medicini i koju je prihvatila Svjetska zdravstvena organizacija.

Nakon velikog uspona farmaceutske industrije u drugoj polovini prošlog stoljeća i značajnog napretka u liječenju osoba s duševnim smetnjama dolazi period razočarenja i prihvaćanja činjenice da sintetski lijekovi nisu svemogući i da imaju ozbiljne i neugodne nuspojave. Zahvaljujući toj činjenici sve je veći interes za liječenje psihičkih poremećaja komplementarnim metodama.

Važno je napomenuti da oni nisu zamjena za standardne metode liječenja niti se njihovom prikladnom primjenom umanjuje ozbiljnost pristupa liječenju psihijatrijskih oboljenja. Postoje brojni pacijenti koji odbijaju klasičnu terapiju i traže nešto od metoda komplementarne medicine. Zato je važno da liječnici i zdravstveni radnici imaju znanje iz komplementarne medicine koja je znanstveno utemeljena i savjetuju im njene metode u liječenju gdje god je to znanstveno opravdano. Ključne riječi: komplementarna medicina, psihijatrija

\section{Kontakt osoba:}

Prof. dr. sc. Ivan Vasilj

E-mail: ivan.vasilj@fzs.sum.ba 


\section{UVOD}

Zvanična medicina posljednih desetljeća u liječenje počinje uvrštavati biljne medikamente i duhovnu terapiju, a posljednjih godina sve se češće i među liječnicima spominju komplementarne metode $u$ liječenju psihičkih poremećaja. U najnovijem izdanju američke psihijatrije "Synopsis of Psychiatry“ obrađeno je poglavlje pod nazivom „Complentary and Alternative medicine in psychiatry" $u$ kome se opisuju 44 alternativne i komplementarne metode $\mathrm{u}$ liječenju psihičkih poremećaja (1).

Medicina koju danas nazivamo alternativnom stara je koliko i ljudski rod, a pisani dokumenti o načinu liječenja datiraju iz vremena od prije 5.000 godina. Primjerice, drevna kineska i egipatska povijest obiluje zapisima o prirodnoj medicini - od liječenja biljem do akupunkture, pružajući nam i danas dragocjene podatke o zdravstvenoj skrbi za čovjeka. Tisućama godina ljudima su za vrlo raznolike psihičke probleme bili na raspolaganju samo prirodni lijekovi i alternativne metode. Alternativna medicina (AM) je danas uvriježen pojam koji podrazumijeva ostale načine liječenja, osim konvencionalne tj. zvanične medicine. Za ovu vrstu liječenja danas je mnogo ispravniji izraz komplementarna koja daje nadopunu zvaničnoj medicini, u načinima liječenja, polazeći od drugačijih načela, ali čiji su rezultati i uspješnost evidentni. Nakon velikog uspona farmaceutske industrije u prošlom stoljeću i značajnog napretka u liječenju dolazi period razočarenja i prihvaćanja činjenice da sintetski lijekovi nisu svemogući. Zahvaljujući toj činjenici posljednjih desetljeća ponovo je sve veći interes za liječenje psihičkih poremećaja alternativnim i komplementarnim metodama (2).

\section{Komplementarna medicina: za i protiv}

Farmaceutska industrija je značajno napredovala i sintetizirala brojne, vrlo kvalitetne psihoaktivne lijekove koji su u značajnoj mjeri pospješili ozdravljenje i popravili kvalitetu života bolesnika. Istovremeno u mnogim razvijenim zemljama dolazi do potiskivanja i odbacivanja prirodnih lijekova i metoda koji su ljudima bili na raspolaganju tisućama godina i čija je učinkovitost i djelotvornost neosporna. Neki narodi, posebice Kinezi, nikada nisu ni prestajali koristiti biljne lijekove u pučkoj medicini, a nasuprot zapadnjačkom metodu liječenja oni još i danas koriste tradicionalne recepte, nerijetko stare i po nekoliko tisuća godina.

Posljednjih desetljeća zapaža se povećanje učestalosti duševnih poremećaja usprkos porastu materijalnog blagostanja i sve većim uspjesima medicine. Zbog čestih razočarenja u sintetske lijekove, posebice zbog ozbiljnih i neugodnih nuspojava, pa i visoke cijene svjedoci smo sve većeg porasta alternativnih $\mathrm{i}$ komplementarnih metoda u liječenju duševnih bolesnika. Tome pogoduje i doktrina liječenja psihijatrijskih bolesnika koja je posljednjih desetljeća multidimenzionalna i integralna, a što podrazumijeva da se u liječenju istovremeno koristi više terapijskih postupaka i da se liječenjem utječe i na bolesnika i na okolinu. Pri tome osim sintetskih sve značajniju ulogu imaju prirodni lijekovi koje propisujemo bilo samostalno bilo u kombinaciji sa sintetskim lijekovima. Nezadovoljni mogućnostima koje pruža tradicionalna medicina i sintetski lijekovi mnogi psihijatrijski pacijenti traže pomoć kod samozvanih iscjelitelja koji su često sumnjivog znanja i morala, egzorcista, skidača uroka, travara i drugih raznovrsnih alternativaca (3). Prema podacima Svjetske zdravstvene organizacije (SZO) oko 80 \% ljudi u svijetu oslanja se na biljke u zadovoljavanju svojih potreba za boljim zdravljem pri čemu potrošnja biljnih lijekova raste u najrazvijenijim zemljama kao što su Njemačka, Francuska, Italija, Japan, Australija, pa i SAD. Podaci pokazuju da je više od $1 / 3$ stanovnika SAD barem jednom u životu isprobalo neki prirodni lijek. U svijetu se koristi oko 20000 ljekovitih biljaka, a od toga je 1100 dobro istraženo, a 250 vrsta ljekovitih biljaka koristi se za dobivanje suvremenih lijekova u medicini. Prema podacima SZO homeopatija je po broju korisnika druga metoda liječenja u svijetu.

Sve je veći broj uglednih medicinskih institucija diljem svijeta koje nude integrativni i komplementarni pristup u liječenju sintetskim i prirodnim lijekovima. U kurikulima mnogih medicinskih fakulteta pojavljuju se predmeti o prirodnim i tradicionalnim metodama liječenja. Mnoge prirodne lijekove 
već su sintetizirale farmaceutske industrije i sve više se provjeravaju u klinički kontroliranim pokusima, koji uz djelotvornost pokazuju da i prirodni lijekovi imaju nuspojave i moguće interakcije sa sintetskim lijekovima (4). Brojne kontrolirane kliničke studije pokazale su, u nekim slučajevima, veću učinkovitost alternativnih metoda u usporedbi s placebom, a jednaku učinkovitost u usporedbi s nekim psihoaktivnim kemijskim lijekovima. One su pokazale neosporno djelovanje, dobru podnošljivost, poznat mehanizam djelovanja uz vrlo blage i rijetke nuspojave te kao takve mogu poslužiti u svakodnevnoj praksi u liječenju duševnih poremećaja.

Riječ komplementarna potječe od lat."complementarius-dopunski“, koji dopunjuje, koji služi kao dopuna ili dodatak nečemu. Najprihvatljivija definicija komplementarne medicine je: komplementarnu medicinu čini grupa dijagnostičkih i terapijskih disciplina koje se koriste zajedno s konvencionalnom medicinom. Komplementarna medicina je dopuna osnovnoj terapiji, vid potpornog tretmana za bolju kontrolu simptoma bolesti. Mnoge metode koje se koriste u komplementarnoj medicini potiču iz tradicionalne medicine. Te metode su dokazane kao sigurne i korisne za bolesnike (5).

Alternativne terapije često se nazivaju i holističkim. To znači da terapeut liječi „čitavu“ osobu, a ne samo simptom, bolest ili stanje. Oficijelna medicina je previše subspecijalizirana, ponekad čak toliko da se nerijetko gubi čovjek kao cjelina (6).

Prema izvještaju eksperata Europske komisije iz 1998.g. o rasprostranjenosti alternativne medicine $u$ Europi, kao i o njenom pravnom statusu, postoje tri vrste zemalja. Najveći dio se nalazi u tzv. monopolističkom sustavu, gdje je dopušteno isključivo prakticiranje službene, znanstveno utemeljene medicine. No, unatoč tomu - navodi se u zaključnom dijelu - opći trend u EU i izvan nje je sve veće prihvaćanje alternativnih metoda i njihovo uključivanje u sustav zdravstvene zaštite. Većina alternativnih terapija postoji izvan domova zdravlja i liječničkih ordinacija, a sve je veći broj liječnika koji znaju i sami da upute svoje pacijente "alternativnim" kolegama.

U SAD postoje i integrirane klinike u kojima zajednički rade ljekari i alternativci, ali takve klinike kod nas još ne postoje. Koncept AM je puno dublji od uzimanja lijekova i terapije koju inzistira službena medicina. Dok se konvencionalna medicina strogo bazira samo na fizički simptom AM uzima u obzir stanje tijela i duše. Pacijenti se često okreću alternativi kada se konvencionalne metode pokažu nedovoljnim ili kada klasična medicina nema lijeka. AM pomaže da se olakša bol, smanji stres i napetost, oslobodi tijelo ubojitih virusa i parazita i poveća prirodna otpornost organizma u borbi protiv bolesti (7).

\section{KOMPLEMENTARNA MEDICINA}

Tehnike komplementarne medicine su brojne, a u novije se vrijeme pridaje važnost znanstvenim istraživanjima komplementarnih tehnika kako bi se potvrdila njihova djelotvornost. Treba naglasiti da metode komplementarne medicine bazirane na iskustvenom liječenju; kojima pripada i biorezonancija, nikako ne isključuju metode klasične medicine već su povezane, nadopunjuju se i sagledavaju zdravstveno stanje čovjeka.

Glavna razlika između komplementarne i klasične medicine je $\mathrm{u}$ tome što komplementarna metoda tretira čovjeka u cjelini, a ne samo njegov pojedinačni, bolesni organ, i u tome što pokušava rješavati uzrok bolesti, a ne vidljivi simptom ili posljedicu na način klasične medicine.

National Center for Complementary and Alternative Medicine (NCCAM) klasificirao je vrste komplementarne medicine u pet skupina:

1. Komplementarni medicinski sistemi - bazirani na teoriji, praksi i znanstvenim dokazima o djelotvornosti. Tu spadaju homeopatija, naturopatija, tradicionalna kineska medicina i ayurveda.

2. Biološke metode - koje uključuju prirodne tvari kao što su ljekovito bilje, hrana, vitamini i minerali u koje spadaju fitoterapija, aromaterapija i nutricionizam.

3. Energetska medicina - uključuje korištenje energije u svrhu poboljšanja zdravlja. Ovdje spadaju bioenergetske metode, Reiki i neke druge energetske tehnike.

4. Manualna medicina temelji se na manipulaciji jednog ili više dijelova tijela. Tu su uključene ma- 
saže, osteopatija, fizikalne terapije, kiropraktika i refleksoterapija.

5. Tehnike relaksacije i duhovnog rasta predstavljaju cijeli niz tehnika i uključuju meditaciju, duboku relaksaciju, vizualizaciju, molitvu, yogu i hipnoterapiju.

Postoje velike razlike u granama komplementarne medicina, ali zajedničko svim metodama i tehnikama je slijedeće:

- žarište interesa je kompletna osoba sa svim njenim segmentima - fizičkim, emotivnim, mentalnim i duhovnim,

- veliki naglasak je na prevenciji bolesti,

- tretmani su individualizirani,

- tretmani su bazirani na rješavanju uzroka bolesti, a ne samo simptoma,

- tretmani pomažu vratiti prirodnu ravnotežu u tijelo.

\section{Prirodni lijekovi koji se koriste u liječenju psihičkih poremećaja \\ Gospina trava - Hypericum perforatum (St. Jo- hn's Wort)}

Oko 2400 godina primjenjuje se u narodnoj medicini u poboljšanju raspoloženja, uklanjanja napetosti i nesanice te $\mathrm{u}$ psihoneurovegativnoj stabilizaciji. Identificirani glavni aktivni sastojak gospine trave je hipericin. Hipericin poboljšava raspoloženje otklanjajući potištenost, osjećaj tuge, melankolije i tjeskobe, nervozu, razdražljivost, malodušnost i bezvoljnost kao i prateće pojave: nesanicu, česte krize plača, umor, pojačan ili smanjen apetit i slično.

Antidepresivni učinak povezuje se inhibicijom monoaminoksidaze A kao i ponovne pohrane serotonina. Ne preporučaju se propisivati istovremeno sa selektivnim inhibitorima ponovne pohrane serotonina i inhibitorima MAO zbog inhibicije monoaminooksidaze i mogućeg serotoninskog sindroma. Terapijska doza je 900-1200 mg dnevno podijeljena u 2 doze uz jelo u trajanju 4-6 tjedana.

Danas se preporuča za liječenje blagih do umjerenih depresivnih i anksioznih poremećaja, sezonskom afektivnom poremećaju, odvikavanju od pušenja, liječenju depresije u menopauzi posebice u osoba koje ne vole kemijske lijekove.
Valeriana - Valeriana officinalis

Zbog svoje učinkovitosti i popularnosti dobila je naziv "prirodni valium», a aktivni sastojak je valproična kiselina koja uspješno otklanja anksioznost i nesanicu tako što pojačava gabaergičnu aktivnost. Preporuča se dnevna doza 50-100 mg ekstrakta. Može pomoći i u odvikavanju od benzodiazepina ali se tada rabi veća doza.

\section{Ginkgo - Ginkgo biloba}

Predstavnik porodice Ginkgocea koji je jedini preživio ledeno doba i atomsku bombu u Hiroshimi. U zapadnoj medicini je sve popularniji i dobiva naziv «antidot za strah od starenja». Aktivna tvar su glikozidi (bioflavonidi) koji su jaki antioksidansi i usporavaju zgrušavanje krvi i glikolidi koji poboljšavaju cirkulaciju i zaštitno djeluju na neurone (Kulier I, 2000). Ublažava ili otklanja simptome vrtoglavice, glavobolje, oslabljenog pamćenja, slabija koncentracija, nesanica, neraspoloženje, osjećaj tjeskobe i straha (8). Indiciran je u liječenju demencije, depresije, vertiga, migrene i impotencije vaskularnog tipa. Uobičajena doza je 120-160 mg/dan.

\section{Omega 3 - masne kiseline}

Preporuča se kao dopunska terapija standardnoj psihofarmakoterapiji različitih oblika depresije, ali i u liječenju bipolarnog afektivnog poremećaja i shizofrenije te osobama koje rade u uvjetima stresa. Popularnost ovog preparata temelji se na činjenici da su Eskimi unatoč ekstremno masnoj hrani zaštićeni o srčanih bolesti zahvaljujući višestruko nezasićenim masnim kiselinama poznatim pod nazivom omega 3.

\section{Kava-kava - Piper methysticum (kawanorum)}

Aktivna tvar su kavapironi koji djeluju anksiolitički pospješujući gabaergičnu aktivnost i smirujući mezolimbički sustav i preko dopaminergičnih i serotoninergičnih neurona. Osim što uklanja anksioznost, poboljšava raspoloženje i kognitivne funkcije bez razvoja ovisnosti. O njoj se u posljednje vrijeme govori kao o biljnoj superzvijezdi koja bi mogla zamijeniti benzodiazepine (9).

\section{Lecitin}

Lecitin je temeljna tvar u staničnim membranama. Njegovim nedostatkom membrana slabi, osobito u moždanom sustavu. Stoga se uzima kod 
smanjenja koncentracije, pamćenja, a ima i mnogo širu funkciiju u zaštiti drugih stanica u našem tijelu i djeluje umirujuće na živčani sustav. Osim toga smanjuje količinu kolesterola, pročišćava stjenke krvnih žila i pojačava rad srčanog mišića. Preporučena doza je 1-2 kapsule od 1250 mg dnevno.

\section{Glycine}

Postoje više istraživanja koja pokazuju da neesencijalna aminokiselina Glicin povećava aktivnost neurotransmitora i smanjuje negativne simptome shizofrenije ako se koristi uz antipsihotičnu terapiju, posebice uz haloperidol, thioridazine i perphenazine (10-12). U liječenju shizofrenije savjetuje se doza 40-90 grama dnevno (1).

\section{Gluten}

Prehrana iz koje su izbačeni gluten (iz žitarica) i kazein (iz mlijeka) poboljšavaju stanje shizofreničara. Dr. Curtis Dohan i njegovi sljedbenici u tri su nutricionističke studije proučavali povezanost prehrane i mentalnih bolesti, osobito shizofrenije. $\mathrm{Na}$ 65.000 ispitanika u Papui, Solomonskim Otocima i Mikroneziji zabilježili su svega dva slučaja shizofrenije dok bi očekivani broj na tom uzorku u Europi bio čak 130. To ih je potaknulo na opširnije istraživanje koje je pokazalo da ti narodi ne jedu žitarice. Radikalniji znanstvenici smatraju da se shizofreničarima kod kojih bolest nije genetski uvjetovana može značajno pomoći izbacivanjem kruha, riže, paste, škroba i rafiniranih šećera (13-15).

\section{Multivitaminski preparati}

Ljudi ne proizvode vitamine - izuzetak je vitamin D - pa ih moraju uzimati iz vanjskog izvora da bi ispravno hranili mozak i ostale organe. B vitamini imaju integrativnu ulogu u funkcioniranju živčanog sustava i pomažu mozgu u sintetiziranju neurotransmitera koji utječu na raspoloženje i mišljenje i mogu biti korisni u liječenju shizofrenih bolesnika. Vitamin C ima važnu ulogu u sintezi neurotransmitera norepinefrina, a neurotransmiteri su od presudne važnosti za mozak i utječu na ponašanje. Vitamin C je također jako djelotvoran antioksidans. Vitamin E stabilizira masne membrane u mozgu i štiti mozak od oštećenja koje nastaje formiranjem slobodnih radikala u stanicama i tako usporava propadanje mentalnih sposobnosti.

\section{Duhovnost}

Od postanka čovječanstava osim različitih somatskih poteškoća čovjek osjećao i različite psihičke smetnje kao što su strah, tuga, nesanica i razni oblici «ludila». Tadašnji nivo medicinskog znanja bio je vrlo nizak. Nije bilo objašnjenja za psihičke smetnje osim što su se pripisivale djelovanju ,viših-duhovnih sila" koje su upravljale materijalnim svijetom. Liječenje se uglavnom vršilo crnom magijom. Zapisano je, da se u to vrijeme u liječenju psihičkih smetnji, osim magije koriste i neznanstvene metode kao što su različite trave, gljive, alkohol i sl. (16). Najstarije medicinske kulture zbog nemogućnosti objašnjenja i nedovoljno dokaza prepoznat će svoje Bogove i Božice kao uzročnike bolesti i nedaća, ali i one druge njihove zaštitnike i pomagatelje u liječenu i čuvanju zdravlja (17).

Između Antičkog doba i moderne psihijatrije, u vrijeme kada Katolička crkva vodi glavnu riječ, dolazi do općeg zastoja napretka u kompletnoj znanosti uključujući i medicinsku struku. Nameće se duhovni pristup, u skladu s Božjim zakonima, a sve uzroke psihičkih tegoba objašnjava utjecajem demona i pokušava psihičke smetnje ljudi liječiti molitvom i egzorcizmom.

Suvremena psihijatrija počinje tvorcem psihoanalize i psihodinamski orijentirane terapije, Sigmundom Freudom (1865-1939), koji svojom teorijom daje značajan doprinos u objašnjenju nastanka i liječenju različitih psihičkih poremećaja. Čovjekovu potrebu za religijom Freud objašnjava kao infantilnu bespomoćnost koja je u ljudi mnogo jača nego u životinja (18). Posljednjih par desetljeća u liječenju psihički oboljelih osoba osim ranije pobrojanih metoda možemo sa sigurnošću priključiti i duhovnu terapiju, tako da ćemo kod svakog pojedinog pacijenta koristiti neku metodu, neku kombinaciju pobrojanih metoda ili sve metode istovremeno.

Međutim, usprkos izuzetno važnoj ulozi koju religija i duhovnost imaju u životu pojedinca i zajednice kojoj pripada te sve više znanstvenih dokaza o pozitivnim učincima duhovnosti na psihičko zdravlje ona se obično ne spominje ili se samo uzgred spominje u udžbenicima psihologije i psihijatrije, ne samo u nas nego i diljem svijeta. Psihologija i psi- 
hijatrija su donedavno za religioznost i duhovnost uglavnom nalazili mjesta samo u patološkom, stoga je područje psihologije religioznosti i njeni pozitivni učinci dugo bilo zanemarivano. Posljednjih desetljeća u znanstvenoj psihijatriji diljem svijeta, a i kod nas se zapaža značajan porast interesa za proučavanje pozitivnih efekata duhovnosti. Svoj doprinos u tom području dali su naši psihijatri i psiholozi (1923).

Vjera nas uči da nas je Bog stvorio zdravima i usadio u naša tijela mehanizme koji mogu održavati zdravlje ako se držimo u skladu s Božjim zakonima. Vjera može značajno pomoći u prevenciji i razrješavanju intrapsihičkih konflikata. Vjera ima moć pokretanja pozitivne energije i može aktivirati zdrave procese koji donose zdravlje. Negativne emocije (bijes, ljutnja, mržnja, anksioznost, krivnja, strah itd.) mogu imati važnu ulogu u nastanku psihičkih poremećaja. Zabrinutost je destruktivan proces ispunjavanja uma mislima suprotno Božjoj ljubavi i brizi. (Nakon što je izdao Isusa Juda si nije mogao oprostiti niti pomiriti s Bogom, bio je preokupiran brojnim negativnim emocijama $i$ izvršio samoubojstvo). Pozitivne emocije (ljubav, radost, nada, optimizam...) i unutarnji mir važna su sastavnica zdravlja. Vjerom kultiviramo svoje emocije, oplemenjujemo svoj emocionalni život. U Biblijskom smislu zdravlje predstavlja čovjekov izbor da za središte svog života izabere Boga. U svakom trenutku svaki čovjek ima slobodu izabrati da svoj život promišlja i živi s Bogom ili bez Boga. Vjera u Boga povećava naše mogućnosti izbora za zdravlje. I kada je čovjek bolestan može se odlučiti da središnja točka njegova života ne bude bolest, već Bog čime se otvara put nade i spasenja (24).

Oduvijek su mnogi ljudi kroz religijske obrede i mistična iskustva pokušavali pobijediti bolest i iznova uspostaviti tjelesnu i psihičku ravnotežu i sklad. Svima je poznato da i najškolovaniji i potpuno nepismeni ljudi u vrlo nepovoljnim zdravstvenim situacijama kada je oficijelna medicina nemoćna odlaze kod raznih svećenika i vračeva kao i u sveta mjesta (Lurd, Ostrog, Međugorje...) tražeći pomoć koju nekada i dobiju.

Većina istraživanja pokazuje da odlazak u crkvu i pripadanje tijelu vjernika koristi zdravlju. U svojoj knjizi Liječenje hardwarea duše američki psihijatar i klinički neuroznanstvenik Daniel G. Amen 2003.g. iznosi podatke Harvardskog medicinskog fakulteta čija istraživanja na uzorku par desetina tisuća pokazuju da: osobe koje svaki dan mole i čitaju Bibliju 40 $\%$ manje ima povišen krvni tlak; za $25 \%$ muškarci i $30 \%$ žene je manja stopa smrtnosti; $70 \%$ se brže oporavlja od depresije; za bolesnike koji svoju snagu pronalaze u vjeri tri puta je vjerojatnije da će preživjeti otvorenu operaciju na srcu; budući da ljudi koji idu u crkvu puše deset puta manje nego oni koji ne idu, njihova stopa krvno žilnih bolesti, raka pluća i kroničnih plućnih bolesti značajno manja. Općenito, ljudi koji idu u crkvu posjeduju snažniji obrambeni sustav od onih koji ne idu, što pridonosi njihovom općenito boljem zdravlju. U jednom izvješću iz 1997.g. koje je objavljeno u Međunarodnom časopisu medicinske psihijatrije, ispitivanje obavljeno na 1700 odraslih osoba pokazalo je da oni koji odlaze na religijske službe imaju manju razinu interleukina-6, imunološke tvari koja prevladava kod ljudi s kroničnim bolestima (25).

Istraživanje na Georgtown Sveučilišta u Americi na uzorku 91.909 vjernika pokazalo je:

1. Aktivan religiozan život ljudi u $75 \%$ slučajeva pomaže da se bolest spriječi, da se brže ozdravi i duže živi.

2. Redoviti posjetioci crkve u $50 \%$ slučajeva rjeđe obolijevaju od bolesti srca nego religiozni apstinenti.

3. U $53 \%$ religioznih ljudi manje pokušavaju ili izvrše samoubojstvo (26).

\section{Duhovnost u liječenju psihičkih poremećaja}

Čovjek je zdrav samo kao cjelovito biće pa u liječenju psihičkih poremećaja treba liječiti tjelesnu, psihičku, socijalnu i duhovnu dimenziju. Postoje brojni nedvojbeni dokazi da vjera i duhovnost imaju svoju pozitivnu ulogu u liječenju psihičkih poremećaja. Poznato je da duhovnost može pomoći u liječenju brojnih neurotskih i psihotičnih poremećaja kao i u liječenju poremećaja ličnosti, ovisnosti i drugih psihičkih poteškoća. Ne postoji niti jedan 
valjan dokaz da vjera, ukoliko se ispravno prakticira, kod onih koji dragovoljno izaberu tu metodu liječenja, može dovesti do narušavanja psihičkog zdravlja zdravih osoba kao i da može dovesti do pogoršanja kod osoba koje imaju određene psihičke poteškoće.

\section{Depresivni poremećaji}

Odnos između vjere i depresije vrlo je složen, aktualna depresija negativno utječe na vjeru i duhovni život oboljelih, a prava vjera može opet mnogo doprinijeti prevenciji i izlječenju depresije. Vjera daje ljudskom životu viši smisao, a gdje god postoji smisao življenja to je brana protiv depresije. Vjera otkriva ljudima jedan nadnaravni duhovni svijet koji je živo vrelo životne snage i ustrajnosti. Ona potiče nadu, daje utjehu, ohrabruje, upravlja misli k optimizmu, a ponašanje $\mathrm{k}$ dobru. Vjera pretvara poraz $\mathrm{u}$ pobjedu, depresiju, sumnju i očaj u sigurnost, radost i blagostanje (27).

Moderna istraživanja sve više govore u prilog tome da bi religioznost i duhovnost mogli zaštitno djelovati na pojavu depresivnosti kao i smanjenje već postojeće depresivnosti. Depresiju karakterizira beznađe, doživljaj besmislenosti nesposobnost doživljavanja ljubavi, osjećaj bespomoćnosti, vlastite bezvrijednosti. Kršćanska vjera koja daje nadu, smisao života u ljubavi, promovira samopoštovanje i poštivanje drugih ima antidepresivni učinak. Vjera je uvijek izvor svjetla koje razgoni tamu depresije. Vjera je štit koji naš štiti od depresije. Ali taj oklop treba svakodnevno održavati. Da bi vjera bila djelotvorna, nisu dovoljne verbalizacije, vjeru treba djelotvorno živjeti (28).

U liječenju depresije primjenjuje se duhovno orijentirana terapija. Ona podrazumijeva duhovni preporod ili duhovnu konverziju koja je nužan proces opraštanja, dobrote i ljubavi za konačnu pobjedu nad depresijom. Spremnost da se priznaju, okaju oproste svi propusti i traume što su nas udaljili od Boga.

\section{Psihotični poremećaji}

Primjena duhovnosti u ovom slučaju mora biti posebice vrlo selektivna i individualno određena. Bolesniku koji prakticira vjeru treba pomoći da izgradi ispravnu sliku Boga, ali i sliku o bolesti od koje boluje i mogućnostima njezina liječenja. Pre- poruča se posebice kod nekih pacijenata u fazama remisije radi uspješnijeg održavanja psihičke stabilnosti i pomoći klasičnim metodama liječenja. Vjera potiče strpljivost i nadu za uspjeh u liječenju, ali isto tako se kroz vjeru uči pozitivno misliti, u sebi buditi pozitivne osjećaje i svoje ponašanje usmjeravati prema dobrim djelima.

\section{Psihosomatske bolesti}

Psihosomatske bolesti su somatske bolesti koje nastaju kao reakcija na produženi neuroendokrini odgovor uvjetovan stresnim situacijama. To su najčešće potisnute bolne emocije (strah, bijes, mržnja, očaj), unutarnji konflikti i psihotraume. Akutni ili kronični emocionalni stresovi, najčešće neprepoznati dovode do pre nadraženosti autonomnog živčanog sustava, oštećenja tkiva različitih organa, slabe čovjekov imunološki sustav i pridonose aktiviranju raznih bolesti (od gripe do karcinoma) (26).

Razborito postupanje s emocijama znači ne izražavati ih impulzivno i bez kontrole; niti ih potiskivati nego ih kontrolirano i umjereno izražavati. Dobro duševno zdravlje ima osoba koja poznaje, prihvaća i voli sebe ispravno, a ne narcistički; ima primjereno društveno ponašanje i zna kontrolirati svoju agresivnost i druge emocije; ne pati od većih tjeskoba, osjećaja krivnje i konflikata unutar vlastite psihe; ne bježi od patnje i u većim iskušenjima ne regredira na infantilne stadije razvoja. Emocionalno stabilna osoba ima osjećaj samopouzdanja, posjeduje samokontrolu, disciplinirano radi $\mathrm{i}$ uživa $\mathrm{u}$ svome radu; ima uzvišene ideale i razumne ciljeve koje može postići svojim radom i sposobnostima. Takva osoba ne živi u iluzijama, zna i hoće učiti na vlastitim pogreškama i rado prima dobronamjerne savjete i kritike, nije tvrdoglava u svojim stavovima, zna se zdravo prilagoditi u novim uvjetima ne žrtvujući pri tome svoje ideale.

Duhovnost nam pomaže da potisnimo negativne, a pojačamo pozitivne emocije, pojačamo psihičku stabilnost i tako uz ostale vidove terapije pobijedimo različite psihosomatske bolesti. Vjerom i molitvom kultiviramo svoje emocije i oplemenjujemo svoj emocionalni život te izravno utječemo na tijek psihosomatskih bolesti. 


\section{Poboljšanje rada mozga pomoću molitve}

Molitva i meditacija uče nas kako se usredotočiti i stišati i disciplinirati um. Umu je potrebno vodstvo $\mathrm{i}$ vježbe da bi dao najbolje što može. Ako se obavljaju na pravilan način, svakodnevne molitve i meditacije pomažu nam da usredotočimo i ojačamo sposobnosti mozga. Te nam tehnike, svojom dosljednošću i ponavljanjem, omogućuju da vladamo sobom. Slično tome, svakodnevne molitve ili meditacije učvršćuju nove neuralne krugove. $\mathrm{K}$ tomu nam daju nadu, a određene molitve i meditacije kao što su „Oče naš i molitva svetoga Franje Asiškoga isto nam tako pružaju i jasne moralne odrednice. Molitva i meditacija suštinski su dio duhovnosti, prosvjetljenja i najboljeg rada mozga.

U brojnim knjigama je zapisano, prema kazivanju legendi, da je indijski mudrac Buddha (2500 g. p.n.e), koji je dao veliki doprinos prosvjetljenju uma putem različitih meditacijskih disciplina, govorio da „neuvježbani um nanosi ti veće zlo od svih tvojih neprijatelja. Dobro uvježbani um pruža ti veće dobrobiti i od onih koje ti može pružiti tvoja majka, otac i cijela tvoja obitelj. Ako ne vladamo svojim umom ne vladamo ni svojim životom“. Ako se naučimo moliti i meditirati to će nam pomoći da zauzdamo um i da svome životu i duši pružimo velike dobrobiti (29).

Um posjeduje nevjerojatnu sposobnost da održava i preuzima kvalitete svega onoga na što je usmjeren. Ako slušamo riječi bijesne osobe i promatramo nasilan prizor, naš um počinje kipjeti od bijesa. Ako se usredotočimo na osobu prepunu ljubavi, naš um će biti preplavljen ljubavlju. Kada jednom to shvatimo, vrlo će nam brzo dvije stvari postati očigledne: 1. kad bismo mogli kontrolirati pažnju, usredotočili bismo se na određene ljude i sjećanja, kako bismo priznali željene kvalitete, kao što su ljubav i radost, 2. ono čime hranimo svoj um podjednako je tako važno kao i ono čime hranimo svoje tijelo. Naša mentalna prehrana utječe na naše mentalno zdravlje. Mudra pažnja... njeguje zdrav um. Postoji ono na što se usredotočujemo i jednom kad budemo mogli kontrolirati pažnju, moći ćemo se usredotočiti na sve što god poželimo (25).

Biblija i učenja drugih velikih religija pružaju nam mnoge upute o tome kako se moliti, kako meditirati, kako stišati i usredotočiti um. Da bi bio u dobroj kondiciji i adekvatno funkcionirao mozak se treba vježbati jednako kao i mišići.

\section{Akupunktura}

Akupunktura je starokineski način liječenja bolesti ubadanjem igala u određene točke na koži i pripada načinu liječenja u sklopu tradicionalne kineske medicine (TKM). TKM je utemeljena na principima kineske filozofije, a pored toga je razvila i osobno učenje o funkcioniranju organa i o faktorima koji remete to funkcioniranje. Mentalne aktivnosti se $\mathrm{u}$ TKM shvaćaju kao vrsta fiziološke funkcije organa i pripisuju se srcu, jetri i bubrezima dok se mozak u ovom smislu ne razmatra. Duševna oboljenja se shvaćaju kao oboljenja ovih organa i liječe se po istim principima kao i tjelesna. Različite emocije se pripisuju različitim organima i njihova pretjeranost može biti i uzrok i posljedica bolesti odgovarajućeg organa. Objašnjenja, dijagnostičke i terapijske procedure, iako izgledaju neobično, predstavljaju potpun i dosljedan sustav i mogu se uspješno koristiti. Akupunktura je našla primjenu i u zapadnoj medicini, a psihijatrija je jedno od polja koja nude mogućnosti za njeno korištenje.

Kineska filozofija, u principu polazi od stava o jedinstvu makrokosmosa i mikrokosmosa. Osnovni principi koji postoje kako u čitavom kosmosu, tako i na nivou tijela, pa i pojedinih njegovih dijelova, su yin i yang. Iako mističnog prizvuka, ovi principi izražavaju odnose dualiteta pojava s kojima se svakodnevno susrećemo, poput dana i noći, muškarca i žene, dobra i zla i svega ostalog. Najprostije rečeno, yin i yang predstavljaju odnose između suprotnih parova istorodnih pojava. Princip yin/yang se smatra osnovnom silom kojoj se podvrgavaju stvari, i u kineskoj kulturi je razrađen u raznim oblastima pa i u medicini. Kratko rečeno, iste sile koje održavaju makrokosmos ili prirodu postoje i u čovjeku i podležu istim zakonitostima. Pored ovih općih principa, koji se po kineskoj filozofiji mogu primijeniti na sve pojave, TKM je razvila i specifičnija učenja koja se tiču anatomije, fiziologije i patofiziologije, a koja su takodje uklopiva u ranije navedeno. Svaki dio tijela ili organ ima svoj yin i yang. Na primjer, gornji dije- 
lovi tijela, lijeva strana i leđa su yang, suprotno ovome je yin, šest parova organa su u međusobnom odnosu pet elemenata, itd. Dok suvremeno znanstveno shvaćanje povezuje psihički život, odnosno mentalne funkcije, sa funkcioniranjem mozga, tradicionalna kineska medicina ga povezuje sa funkcijama ovih organa. Razlikuje se pet osnovnih emocija i svaka od njih pripada nekom organu: ljutnja jetri, radost srcu, razmišljanje slezini, tuga plućima, a strah bubregu. Ukupna funkcija središnjeg živčanog sustava koju mi poznajemo, u TKM zavisi od aktivnosti srca (mentalna aktivnost, emocionalna stanja), jetre (djelomično emocionalnost, utjecaj na protok krvi) i bubrega (razvoj struktura CNS i njihovo održavanje). U većini europskih zemalja akupunktura je danas priznata medicinska metoda i uvrštena je kao predmet na nekim medicinskim fakultetima (7).

SZO je priznala i izjednačila akupunkturu sa svim priznatim metodama liječenja 1979. godine i preporuča ju kao metodu izbora pri liječenju četrdesetak oboljenja. Ta se posebno odnosi na bolna stanja kod kojih nema organskih oštećenja i gdje je bol funkcionalne naravi. U psihijatriji se savjetuje za liječenje: anksioznosti, depresije, nesanice, neurastenije, disocijativnih poremećaja, anoreksije, shizofrenije, bolesti ovisnosti i gojaznosti. Rezultati više stručnih i znanstvenih radova kao i iskustva u kliničkom području učinak akupunkturne igle potvrđuju endokrinohumoralnom teorijom, tj. pojačanim lučenjem hormona, neurotransmitera i analgetskih tvari, te neka istraživanja navode da ima manje nuspojava u liječenju anksioznih poremećaja od konvencionalne terapije (30). To je sigurna metoda ako je provode pravilo izučeni stručnjaci (31).

\section{Metode komplementarne medicine koje se rjeđe koriste u psihijatriji}

Ajurveda ('znanost života') je sustav tradicionalne medicine koji potječe iz Indije i koristi metode za postizanje fizičkog, mentalnog i duhovnog zdravlja i dobrobiti. Ajurveda naglašava prevenciju i holistički pristup terapiji, a prakticira se kao forma CAM u zapadnom svijetu, gde su neke od njenih metoda, kao što su primjena biljaka, masaže i joge primjenjuju samostalno kao oblik CAM tretmana.
Kiropraktika se najčešće koristi za tretman neuro-mišićnoskeletnih tegoba, uključujući, ali ne ograničeno samo na bol u leđima, bol u vratu, bol u zglobovima ruku i nogu i glavobolje. Kiropraktičari liječnici ili kiropraktičari terapeuti prakticiraju prisutup šakama koji uključuje pregled pacijenta, dijagnozu i tretman. Oni imaju niz dijagnostičkih vještina, a trenirani su i da preporuče terapeutske i rehabilitacijske vježbe kao i savjete vezane za ishranu i stil života.

Homeopatija je cjelokupan medicinski sustav koji potječe iz Njemačke. Osnovna ideja homeopatije je princip sličnosti, koji kaže kako supstance koje su sposobne izazvati poremećaj kod zdrave osobe, mogu se koristiti kao ljekovito sredstvo za tretman sličnih tegoba koje se javljaju kod bolesne osobe. Homeopatska sredstva imaju za cilj usmjeriti i stimulirati samoregulatorne mehanizme tijela. Homeopatija je visoko individualizirana, jer uzima u obzir simptome i znake bolesti, fizičku konstituciju pacijenta, ličnost, temperament i genetsku predispoziciju. Pored homeopatske terapije, savjeti o promjeni stila života, ishrani, bolestima ovisnosti, tehnikama oslobađanja od stresa su također dio paketa.

Kineziologija je jedinstveni specifični pristup klijenta, zdravlja i dobrobiti. Primjenjuje se „test mišićnog odgovora" kako bi se dobila povratna informacija od tijela, na podsvjesnom refleksivnom nivou. Kao odgovor na blagi pritisak, zgrčen mišić se promatra kao pozitivan odgovor na „dolazeći stres“ kao što je tvrdnja, sjećanja, hrana ili edukacijska aktivnost. Slab ili nezgrčen mišić ukazuje na negativan odgovor, nedostatak lakoće. Primjenjenu kineziologiju je prvi put razvio kao terapiju 1960-ih godina dr. Joseph Goodheart, a podržan je istraživanjima oko 18 drugih kiropraktičara. Jedan od njih, dr. John Ti je ponudio pravac kineziologije Dodir za zdravlje, kao granu primjenjene kineziologije. Odatle se kineziologija razvila kao samostalna terapija. Tijekom kineziološke sesije simultano se tretiraju mentalni, kemijski, fizički, energetski i aspekti okoline samog problema. Kineziologija nudi izbor tehnika i preparata iz kiropraktike, tradicionalne kineske medicine i drugih izvora kako bi se podržalo iscjeljenje (7). $\mathrm{Na}$ našem sveučilištu provedeno je nekoliko istraživa- 
nja u kojima je dokazan pozitivan utjecaj tjelovježbe na zdravlje (32-35).

\section{ZAKLJUČAK}

Zbog sve većeg interesa javnosti za komplementarne metode liječenja kao i nekih dokaza o njihovoj terapijskoj učinkovitosti potrebno je da ih liječnici ne samo poznaju nego i primjereno savjetuju. Preporučamo komplementarne metode liječenja koje su dokazano sigurne, temeljito proučene, a njihovi učinci znanstveno potvrđeni. Važno je napomenuti da oni nisu zamjena za standardne metode liječenja niti se njihovom prikladnom primjenom umanjuje ozbiljnost pristupa liječenju psihijatrijskih oboljenja. Treba ih, uz oprez, savjetovati uz terapiju koju preporuča zvanična medicina osobama koje ne vole ili teško prihvaćaju «kemijske» lijekove kao dopunsku terapiju standardnim psihoaktivnim lijekovima. Potrebno je nastaviti istraživanja i potpuno rasvijetliti učinkovitost i mehanizam djelovanja komplementarnih i alternativnih metoda liječenja.

\section{LITERATURA}

1. Kaplan \& Sadock's. Synopsis of Psychiatry. Behavioral Sciences/Clinical. LW\&W. Philadelphia. PA191006 USA, 2007.

2. Babić D \& Babić R.Complementary and alternative medicine in the treatment of schizophrenia. Psychiatr Danub. 2009;21(3):376-81.

3. Babić D. Herbal medicine in the treatment of mental disorders. Psychiatria Danubina, 2007:19(3)241-4.

4. Jakovljević M. Mihaljević-Peleš A, Šagud M, Rajačić M: Herbal Medicine in Treatment of Mental Disorders -Medicus, 2002:11(2):263-9.

5. Maličević Ž. Alternativna i komplementarna medicina. Vojnomedicinska akademija, Sektor za školovanje i naučnoistraživački rad, Beograd, 2006., str. 55.

6. O’Mathuna, Donald i Larimore, Walt: Alternativna medicina, Stepress i Veritas Zagreb, Zagreb, 2009., str. 25.

7. Babić D i sur. Psihijatrija. Sveučilište u Mostaru. Mostar, 2018.

8. Itil TM i sur. Central Nervous System Effects of
Ginkgo Biloba, a Plant Extract. Am J Therapeutics 1996:(3)63-73.

9. Bloomfield H: Healing Anxiety with Herbs. Thorsons. An Imprint of harperColins Publichers, 1998.

10. Waziri R: Therapy schisophrenia with glycine: any caveatus. Psychiatria Biol, 1996; 39155-6.

11. Heresco Levy-U i sur. Efficacy of high-dose glycine in the treatment of enduring negative symptoms of schizophrenia. Arch Gen Psychiatry. 1999;56:29-36.

12. Javitt DC i sur. Amelioration of negative symptoms inschizophrenia by glycine. The American Journal of Psychiatry, 1994;151:1234-6.

13. Potkin SG, Weinberger D, Kleinman J i sur. Wheat gluten challenge in schizophrenic patients. Psihijatriju Am J 1981;138:1208-11.

14. Ross Smith-P \& Jenner FA. Diet (gluten), schizofrenia. J Hum Nutr 1980; 34:107-12.

15. Kelly DL, Demyanovich HK, Rodriguez KM, Ciháková D, Talor MV, McMahon RP. Randomized controlled trial of a gluten-free diet in patients with schizophrenia positive for antigliadin antibodies (AGA IgG): a pilot feasibility study. J Psychiatry Neurosci. 2019;44(4):269-276.

16. Kecmanović D. Historija pristupa duševno poremećenom čovjeku. Psihijatrija. Medicinska knjiga Beograd - Zagreb. 1991.

17. Škrobonja A. Sveti od zdravlja. Kršćanska sadašnjost. Zagreb. 2004.

18. Palmer M. Frojd i Jung o religiji. Narodna knjiga Alfa, Beograd. 2001.

19. Jakovljević M. The brave new psychiatry: A pluralistic integrating transdisciplinary approach in theory and practice. Psychiatria Danubina 2007; 19:262-269.

20. Jakovljević M. Transdisciplinarna holistička integrativna psihijatrija; iznad modernizma, antipsihijatrije i postmodernizma. U: Jakovljević i sur. Nove ideje i koncepti u suvremenoj psihijatriji. Pro Mente d.o.o. Zagreb. 2008.

21. Jukić V. Je li danas psihoterapija zamjena za ispovijed? Vjera i zdravlje. Urednici: M. Jurčić, M. Nikić, H. Vukušić. Zaklada biskup Josip Lang Zagreb. 2005. 
22. Babić D. Novi koncepti liječenja psihijatrijskih bolesnika u primarnoj zdravstvenoj zaštiti. U: Jakovljević i sur. Nove ideje i koncepti u suvremenoj psihijatriji. Pro Mente d.o.o. Zagreb. 2008.

23. Dilber R, Babić D, Vasilj I, Martinac M, Babić $\mathrm{R}$, Aukst-Margetić B. Religiosty and mental health in nursing students. Psychiatria Danubina. 2016:28;188-192.

24. Nikić M. Psihologija sugestije i snaga vjere. Vjera i zdravlje. Urednici: M. Jurčić, M. Nikić, H. Vukušić. Zaklada biskup Josip Lang Zagreb. 2005.

25. Amen DG. Liječenje hardwarea duše. Biblioteka 21 Zagreb. 2003.

26. Jerotić V. Hrišćanstvo i medicina. Vjera i zdravlje. Urednici: M. Jurčić, M. Nikić, H. Vukušić. Zaklada biskup Josip Lang Zagreb. 2005.

27. Jakovljević M. Current status of religion and spirituality in psychiatry. Psychiatria Danubina, 2005;17:(3-4):138-40.

28. Jakovljević M. Vjerom protiv depresije. Pro menta Croatica. Zagreb. 1997(2):73-5.

29. Walsh R. Esencijalna duhovnost - zajednička mudrost svjetskih religija. Gorin Rijeka. 2006.
30. Amorim D, Amado J, Brito I, Fiuza SM, Amorim N, Costeira C, Machado J i sur. Acupuncture and electroacupuncture for anxiety disorders: A systematic review of the clinical research. Complement Ther Clin Pract. 2018;31:31-7.

31. Mallory MJ, Do A, Bublitz SE, Veleber SJ, Bauer BA, Bhagra A. Puncturing the myths of acupuncture. J Integr Med. 2016 Sep;14(5):311-4.

32. Katić S, Kvesić M, Lukanović B, Babić M. Učinak tjelovježbe na kvalitetu života žena srednje životne dobi. Zdravstveni glasnik. 2018;2:25-32.

33. Babić M, Čerkez Zovko I, Martinac M, Babić R, Katić S, Lukanović B. Povezanost tjelovježbe i duševnog zdravlja studenata. Zdravstveni glasnik. 2018;2:33-43.

34. Lukanović B, Babić M, Katić S, Čerkez Zovko I, Martinac M, Pavlović M \& Babić D. Mental Health and Self-Esteem of Active Athlets. Psychiatria Danubina. 2020: 32 (2), 236-243.

35. Markotić V, Pokrajčić V, Babić M, Radančević D, Grle M, Miljko M et al. The Positive Effects of Running on Mental Health. Psychiatria Danubina 32 (2), 233-235. 


\title{
COMPLEMENTARY MEDICINE IN PSYCHIATRY
}

\author{
Robert Barbarić1,2 \& Ivan Vasilji \\ Faculty of Health Studies University of Mostar ${ }^{1}$ \\ Clinic for Psychiatry University Clinical Hospital Mostar ${ }^{2}$ \\ 88000 Mostar, Bosnia and Herzegovina
}

\begin{abstract}
In recent decades, conventional medicine has begun to include natural remedies and spiritual therapy in the treatment of people with mental disorders, and in recent years, physicians and healthcare professionals more often refer to alternative and complementary methods in the treatment of mental disorders. Alternative medicine includes "other treatments" and a more suitable term would be complementary medicine which supplements the definition of conventional medicine accepted by the World Health Organization.

After the rise of pharmaceutical industry in the second half of the $20^{\text {th }}$ century and significant advancement in the treatment of mental disorders, comes a period of disappointment and acceptance of the fact that synthetic drugs are not omnipotent and may have serious and unpleasant side-effects. Due to this fact, there is a growing interest in the treatment of mental disorders with the use of complementary methods.

It is important to note that these methods are not a substitute for standard treatment procedures and their appropriate application does not diminish the importance of classical treatment of psychiatric disorders. Numerous patients refuse classical therapy and seek the help of complementary medicine methods. It is therefore important for physicians and healthcare professionals to have knowledge of complementary medicine which is science based and advises on treatment methods provided they are scientifically justified.
\end{abstract}

Key words: complementary medicine, psychiatry

Correspondence:

Professor Ivan Vasilj, MD, PhD

E-mail: ivan.vasili@fzs.sum.ba 